\title{
MAKNA YURIDIS STATUS HUKUM HAK WARIS ANAK HASIL DARI PERKAWINAN SIRI MENURUT KOMPILASI HUKUM ISLAM
}

\author{
Zidna Nama \\ Kantor Notaris Kab. Blitar (Syamsyul Ichwani, SH) \\ Jl. Raya Wlingi Kec. Wlingi / Blitar \\ Email: zie2zidna@gmail.com
}

\begin{abstract}
The aim of this jurnalis to determine the meaning of judicial and juridical implications of the legal status of the inheritance rights of a child who is born from the siri marriage accordingto KHI. The method used in this jurnal is a normative study by using conceptual approach of legislation and then assisted with legal materials that will be outlined, described, and analyzed its relationship between one and another.A child can become an heir according to Islam is based on family lineage that come fromthe existence of a valid marriage according to the religion. According to KHI, the validity of a marriage not only has to fulfill the requirements of valid marriage but also has to fulfill the registration of the marriage. If not, it will cause a marriage that has no legal force, and it will impact to the inheritance relationship that is not going to have a legal force as well. The implication of the juridical status of the inheritance rights of children from an siri marriage is there is no protection of law and justice, due to a loss of status for the child's inheritance rights.
\end{abstract}

Key words: inheritance rights, child who is born from the siri marriage, compilation of islamic law

\begin{abstract}
Abstrak
Jurnal ini bertujuan untuk mengetahui makna yuridis dan implikasi yuridis status hukum hak waris anak yang dilahirkan dari perkawinan siri menurut KHI. Metode yang digunakan dalam jurnal ini adalah penelitian yuridis normatif, dengan menggunakan pendekatan perundangundangan yang bersifat konseptual. Kemudian dibantu dengan bahan-bahan hukum yang akan diuraikan, dideskripsikan, dan dianalisis keterkaitan satu sama lain. Seorang anak dapat menjadi ahli waris menurut agama Islam selalu berdasar pada adanya hubungan nasab yang ditimbulkan dari adanya perkawinan yang sah menurut agama,tetapi menurut KHI untuk sahya suatu perkawinan selain harus memenuhi rukun dan syarat perkawinan juga harus memenuhi syarat pencatatan,yang jika tidak dilakukan akan berakibat perkawinan tersebut tidak mempunyai kekuatan hukum. Implikasi yuridis terhadap status hak waris anak dari perkawinan siri yaitu belum terwujudnya perlindungan hukum dan keadilan, karena terhapusnya status hak waris bagi anak tersebut.
\end{abstract}

Kata kunci: hak waris, anak hasil dari perkawinan yang tidak dicatatkan, kompilasi hukum islam 


\section{Latar Belakang}

Setiap insan manusia baik laki-laki ataupun perempuan telah dikarunia adanya rasa saling mencintai, dan karena manusia mempunyai akal, menganut agama dan kepercayaan, serta taat terhadap hukum, maka untuk memenuhi hasrat saling mencintai dan untuk memiliki satu sama lain tersebut diwujudkan dengan adanya suatu lembaga perkawinan.

"Lembaga perkawinan dalam
hukum Islam merupakan bentuk
ikatan sakral antara seorang laki-
laki dan perempuan berdasar
dari perasaan cinta dan kasih
sayang, yang berpedoman pada
beberapa ketentuan Al-Quran yang
menggambarkan bahwa lembaga
perkawinan mempunyai kedudukan
yang sangat penting dalam hukum
kekeluargaan, hal ini disebabkan
lembaga perkawinan selain menjaga
kesucian atau kehormatan setiap
manusia dari perbuatan zina
juga dapat menjadi penghubung
kelangsungan regenerasi umat
manusia."

Secara alamiah setiap laki-laki dan perempuan mempunyai daya tarikmenarik antara satu dengan yang lainnya untuk dapat hidup bersama membentuk ikatan lahir dan batin dengan wujud suatu perkawinan, yang selain untuk melanjutkan keturunan, dan menyalurkan fitrah seksual, sebuah perkawinan bertujuan pokok untuk menciptakan rumah tangga yang rukun, bahagia, dan sejahtera selamanya. Hukum dasar perkawinan dalam agama Islam adalah sunnah dan menjalankannya adalah sebagai wujud ibadah kepada Allah SWT.

Dahulu pada masa Nabi Muhammad SAW suatu perkawinan sudah dianggap sah apabila memenuhi rukun dan syarat perkawinan dan hendaknya dilakukan dengan diumumkan kepada masyarakat luas, yaitu dengan diadakannya walimatul ursy, tetapi dengan adanya perkembangan jaman yang selaras mengikuti perkembangan masyarakat di Indonesia, suatu perkawinan akan sah apabila dilaksanakan sesuai dengan peraturan perundangan-undangan yang berlaku, yaitu dilakukan menurut hukum agama dan kepercayaan setiap umat manusia sebagaimana tersebut dalam Pasal 2 ayat (1) Undang-undang Republik Indonesia Nomor 1 Tahun 1974 tentang Perkawinan (selanjutnya disebut dengan Undang-undang Perkawinan) dan pasal 4 Kompilasi Hukum Islam (selanjutnya disebut dengan KHI). Selain itu, dalam peraturan perundang-undangan juga menyebutkan bahwa dalam setiap perkawinan diadakan pencatatan (pasal 2 ayat (2) Undangundang Perkawinan dan pasal $5 \mathrm{KHI}$ ), hal ini dimaksudkan untuk terciptanya ketertiban pelaksanaan perkawinan, terciptanyakepastian hukum, dan untuk melindungi pihak-pihak yang melakukan perkawinan itu sendiri serta akibat dari terjadinya perkawinan, seperti nafkah istri, hubungan orang tua dengan anak, kewarisan, dan lain-lain. 
Apabila dalam suatu perkawinan tidak dilakukan pencatatan oleh Pegawai Pencatat Nikah (PPN) khususnya bagi yang beragama Islam di catatkan di Kantor Urusan Agama (KUA), maka dalam perkembangan hukum Islam di Indonesia perkawinan seperti inilah yang disebut dengan perkawinan siri, dimana pengertian tentang perkawinan siri yang sekarang berbeda dengan pengertian perkawinan siri pada masa dahulu. Pada jaman Rasulullah yang dimaksud dengan perkawinan siri adalah suatu perkawinan yang telah memenuhi rukun dan syarat perkawinan menurut syari'at, namun para saksi diminta merahasiakan terjadinya perkawinan tersebut kepada masyarakat, dan dengan demikian otomatis tidak terdapat walimatul-ursy.

“Aturan hukumdi Indonesiasekarang ini, apabila suatu perkawinan dilaksanakan tanpa dicatatkan akan berakibat adanya konsekuensi yang lebih jauh, diantaranya negara tidak dapat melindungi status perkawinan, harta gono-gini/ harta bersama, hak waris, dan hak-hak lain yang muncul akibat dari perkawinan tersebut, karena untuk mengetahui bahwa benar terdapat hak istri ataupun hak anak yang terlahir dalam perkawinan tersebut, harus dengan pembuktian adanya perkawinan yang sah menurut agama dan menurut hukum negara antara istri dengan suaminya." 2

Dapat disimpulkan bahwa dengan dilakukannya perkawinan siri akan mempunyai dampak negatif selain terhadap istri juga berdampak kepada anak yang dilahirkannya. Status hukum anak yang terlahir akibat dari perkawinan siri akan menjadikan anak tersebut tidak sah di mata hukum, yang berakibat di dalam akta kelahirannya pun statusnya dianggap sebagai anak luar kawin. Ada beberapa alasan menurut ilmuwan di Indonesia yang menjadikan istilah anak yang dilahirkan dari perkawinan siridikatakan sebagai anak luar kawin, tetapi dalam peraturan perundang-undangan sama sekali belum ada yang mengatur kepastian hal tersebut.

Peraturan perundang-undangan yang berlaku di Indonesia tidak mengenal istilah anak yang dilahirkan akibat dari perkawinan siri, selain itu juga tidak ada yang menyebutkan tentang pengertian istilah anak luar kawin, dalam peraturan perundang-undangan hanya menyebutkan tentang pengertian anak sah, yaitu terdapat dalam pasal 42 Undang-undang Perkawinan menyebutkan bahwa pengertian anak sah yaitu anak yang dilahirkan sebagai akibat dari suatu perkawinan yang sah, serta pasal 99 KHI menyebutkan pengertian tentang anak sah yaitu anak yang dilahirkan sebagai akibat dari perkawinan yang sah atau hasil dari pembuahan antara suami dan istri yang sah di luar rahim istri dan dilahirkan oleh istri tersebut, sehingga untuk mengetahui pengertian anak luar kawin terpaksa harus memahami dengan arti yang berlawanan terhadap pasal-pasal tersebut, yaitu bahwa anak luar kawin adalah anak yang tidak

2 Shedharyo Soimin, Hukum Orang dan Keluarga, Sinar Grafika, Jakarta, 2004, hlm. 31. 
dilahirkan dalam atau sebagai akibat dari perkawinan yang sah atau anak yang tidak dihasilkan dari pembuahan suami istri yang sah di luar rahim dan dilahirkan oleh istri tersebut.

"Di Indonesia sendiri pada umumnya mengartikan istilah anak luar kawin didasarkan pada latar belakang terjadinya anak luar kawin, antara lain terjadinya anak luar kawin dibedakan atas anak yang terlahir dari perkawinan yang tidak dicatat serta anak yang lahir karena tanpa hubungan perkawinan, dan dalam hal ini istilah anak yang terlahir dari perkawinan siri juga disebut sebagai anak luar kawin." ${ }^{3}$

Pasal 43 Undang-undang Perkawinan menyebutkan bahwa anak yang terlahir di luar perkawinan berakibat hukum hanya akan mempunyai hubungan perdata dengan ibu serta keluarga ibunya dan pasal $100 \mathrm{KHI}$ menyebutkan bahwa anak yang terlahir di luar perkawinan berakibat hukum hanya akan mempunyai hubungan nasab dengan ibu serta keluarga ibunya. Pasal-pasal tersebut memiliki tafsiran bahwa anak yang dilahirkan di luar perkawinan tidak akan mempunyai hubungan perdata/ hubungan nasab dengan ayah ataupun keluarga ayahnya.

"Status hukum seorang anak sebagai ahli waris terhadap orang tuanya yang meninggal merupakan golongan yang utama, karena pada hakikatnya kerabat yang lain tidak akan mendapat bagian waris atau terhalang menjadi ahli waris apabila pewaris meninggalkan anak. Hal ini berlaku sama pada Hukum Adat, Hukum Islam, maupun dalam Kitab Undang-undang Hukum Perdata (selanjutnya disebut dengan $\mathrm{KUH}$ Perdata)." ${ }^{4}$

Oleh karena itu, status hukum anak dalam hubungan kewarisan sangatlah penting dikarenakan anak adalah keturunan yang akan menjadi penerus dari kedua orang tuanya, selain itu kedua orang tuanya juga mengemban kewajiban untuk mengurus dan memberikan nafkah kepada anak mereka, sudah seharusnya apabila anak menjadi pihak yang pertama sebagai ahli waris yang didahulukan, tetapi dengan adanya perbedaan status anak antara anak sah dengan anak luar kawin yang diakui maka akan berdampak berbeda pula terhadap pembagian harta waris diantara keduanya.

"Hukum waris secara keseluruhan merupakan bagian dari hukum perdata, sedangkan pada hukum kekeluargaan hukum waris merupakan bagian terkecil. Hukum waris juga erat hubunganya dengan ruang lingkup kehidupan setiap manusia, hal ini dikarenakan pada kehidupan setiap manusia pasti akan mengalami kematian." 5

Kematian merupakan peristiwa hukum yang mempunyai akibat hukum yang terkait dengan masalah kepengurusan dan kelanjutan hak-hak serta kewajiban-kewajiban seseorang yang meninggal dunia tersebut.

3 D.Y. Witanto, Op.cit., hlm. 146-148.

4 Shedharyo Soimin, Op.cit.

5 Wirjono Prodjodikoro, Hukum Warisan di Indonesia, Sumur Bandung, Bandung, 1983, hlm. 11. 
"Kepengurusan dan kelanjutan penyelesaian hak-hak dan kewajiban setiap orang yang meninggal diatur oleh hukum, dengan pengertian bahwa hukum waris itu merupakan ketentuan yang mengatur tentang tata cara penerusan dan peralihan harta kekayaan baik itu berupa harta berwujud maupun tak berwujud dari pewaris kepada ahli waris." 6

Di Indonesia sendiri terdapat tiga macam hukum waris yang berlaku di masyarakat, pertama yaitu sistem waris hukum adat yang bercorak patrilineal, matrilineal, dan parental atau bilateral. Kedua, yaitu sistem waris hukum Barat yang tercantum pada Burgerlijk Wetboek. Ketiga, yaitu sistem waris hukum Islam yang mempunyai pengaruh mutlak terhadap orang Indonesia asli di berbagai daerah.

Anak yang dilahirkan dari perkawinan siri yang menjadikan status hukumnya menjadi anak luar kawin, menurut Hukum Islam menimbulkan akibat hukum yaitu hanya akan mempunyai hubungan saling mewaris dengan ibu serta keluarga ibunya (sesuai dengan Pasal $186 \mathrm{KHI})$.

Istilah anak luar kawin yang diartikan sebagai anak yang dilahirkan dari hasil hubungan laki-laki dan perempuan yang tidak terikat perkawinan dengan orang lain serta tidak ada larangan untuk melangsungkan perkawinan, menurut konsepsi hukum Barat dapat memiliki hubungan perdata dengan orang tuanya apabila orang tua kandungnya melakukan pengakuan. Hal ini terlihat dalam Pasal 272 dan Pasal 280 KUH Perdata, yang isinya dapat disimpulkan bahwa anak luar kawin selain anak zina dan anak sumbang dapat memiliki hubungan perdata dengan ayah dan ibunya apabila terdapat pengakuan. Pengakuan tersebut menimbulkan akibat hukum yaitu adanya hubungan saling mewaris dengan kedua orang tuanya, sebagaimana tercantum pada Pasal 863, Pasal 865, dan Pasal 870 KUH Perdata.

Tidak ada pasal dalam KUH Perdata yang menguraikan tentang istilah tentang perkawinan yang tidak dicatatkan, demikian juga dengan status hukum dan akibat hukumnya, karena istilah perkawinan siri di Indonesia baru muncul setelah berlakunya Undang-undang Perkawinan yang mencantumkan adanya pencatatan dalam perkawinan, tetapi secara logika apabila kedudukan anak luar kawin dalam arti sempit dalam KUH Perdata masih dimungkinkan adanya pengakuan. Dirasa tidak adil apabila anak hasil perkawinan siriyang dipandang sah menurut ketentuan agama dan kepercayaan masih dipermasalahkan di mata hukum negara dan sulit untuk mendapatkan pengakuan.

"Pengakuan anak yang dilahirkan dari perkawinan siri dalam pemahaman umum, terlebih dahulu dapat dilakukan dengan mengajukan itsbat nikah yang diatur dalam Pasal 7 KHI." 7

6 H. Hilman Hadikusuma, Hukum Waris Adat, Citra Aditya Bakti, Bandung, 2003, hlm. 8.

7 Kasuwi Saiban, Hukum Waris Islam, Universitas Negeri Malang (UM PRESS), Malang, 2007, hlm. 83-84. 
Seperti halnya yang diuraikan di atas tentang diperbolehkannya adanya pengakuan terhadap anak yang dilahirkan akibat perkawinan siri setelah adanya itsbat nikah, juga belum diatur dalam peraturan perundangan-undangan terutama dalam KHI sebagai dasar masyarakat yang beragama Islam, sehingga masih terdapat kekaburan dalam pelaksanaannya.

Berbeda dengan setelah munculnya Putusan Mahkamah Konstitusi Nomor 46/ PUU-VIII/2010 yang memaparkan bahwa Pasal 43 ayat (1) Undang-undang Perkawinan harus ditafsirkan sebagai berikut:

"Seorang anak yang terlahir di luar perkawinan selain mempunyai hubungan perdata dengan ibunya dan keluarga ibunya juga mempunyai hubungan perdata dengan ayahnya dan keluarga ayahnya, di mana hal ini dibuktikan ilmu pengetahuan dan teknologi dan/atau alat bukti lain yang menurut hukum terbukti mempunyai hubungan darah"

\section{Pelaksanaan Putusan Mahkamah}

Konstitusi ini diwujudkan dalam Pasal 49 ayat (2) Undang-undang Republik Indonesia Nomor 24 Tahun 2013 tentang Perubahan Undang-undang Republik Indonesia Nomor 23 Tahun 2006 tentang Administrasi Kependudukan yang menguraikan bahwa pengakuan terhadap anak hanya berlaku bagi anak yang perkawinan orang tuanya telah dilangsungkan secara sah menurut hukum agama, tetapi belum didaftarkan atau belum sah menurut hukum negara.

Tulisan ini berdasarkan hasil penelitian hukum yuridis normatif dengan mengkaji aplikasi hukum positif serta dibantu dengan adanya literatur-literatur yang terkait tentang makna yuridis status hukum hak waris anak yang dilahirkan dari perkawinan sirimenurut KHI.

Penulisan penelitian ini menerapkan metode penelitian kepustakaan yang bersifat yuridis normatif, yang dalam hal ini dilakukan untuk memperoleh data sekunder, diantaranya meliputi bahan hukum primer (bahan-bahan hukum yang berupa peraturan perundang-undangan yang berkaitan dengan permasalahan ${ }^{8}$, bahan hukum sekunder(bahan hukum yang meliputi buku-buku, artikelartikel yang berfungsi memberikan penjelasan dan informasi terhadap bahan hukum primer) ${ }^{9}$, dan bahan hukum tersier (bahan penunjang yang akan membantu memberikan petunjuk terhadap bahan hukum primer dan sekunder yang dikaji $)^{10}$. Setelah semua data terkumpul, data akan diolah dan dianalisa secara kualitatif yakni dalam bentuk uraian yang menghubungkan antara teori dengan hasil penelitian, selanjutnya dianalisis secara deskriptif analisis, yaitu peneliti berkeinginan menganalisis untuk memberikan gambaran atas subyek dan obyek penelitian. Logika hukum yang digunakan bersifat deduktif

8 Soerjono Soekanto dan Sri Mahmudji, Penelitian Hukum Normatif suatu Tinjauan Singkat, RajaGrafindo Persada, Jakarta, 2003, hlm. 13.

9 Ibid.

10 Ibid. 
kualitatif yaitu berawal dari pengetahuan hukum bersifat umum yang diperoleh dari peraturan perundang-undangan dan literatur yang kemudian diimplementasikan untuk menjawab permasalahan.

Berdasarkan uraian-uraian di atas, maka permasalahan yang diangkat dalam penulisan jurnal ini adalah sebagai berikut: 1) Apa makna yuridis status hukum anak yang dilahirkan dari perkawinan siri menurut KHI dan 2) Bagaimana implikasi yuridis status hukum hak waris anak yang dilahirkan dari perkawinan siri menurut KHI. Dengan tujuan untuk mengetahui makna yuridis status hukum hak anak yang dilahirkan dari perkawinan sirimenurut KHI dan untuk mengetahui implikasi yuridis status hukum hak waris anak yang dilahirkan dari perkawinan siri menurut KHI.

\section{Pembahasan}

\section{A. Makna Yuridis Status Hukum Hak Waris Anak yang Dilahirkan Hasil dari Perkawinan Siri menurut Kompilasi Hukum Islam}

Untuk memperoleh sahnya suatu perkawinan dalam syari'at agama Islam hanya dengan terpenuhinya rukun dan syarat perkawinan, sedangkan untuk memperoleh status hukum suatu perkawinan dalam ketentuan KHI selain harus memenuhi ketentuan hukum Islam sesuai pasal $4 \mathrm{KHI}$, juga harus dicatat pada lembaga Negara sesuai Pasal 5 dan Pasal 6 KHI.
Secara hukum negara dapat atau tidaknya timbul status hukum dalam suatu perkawinan tergantung dari segi mana Pasal 2 ayat (1) dan (2) Undang-undang Perkawinan ditafsirkan, yaitu pertama suatu perkawinan diartikan dilangsungkan sesuai dengan ketentuan agama dan kepercayaan yang juga disertai dengan pencatatan, dimana hal ini bertujuan untuk menjamin terlaksananya secara hukum setiap perbuatan dan peristiwa yang akan ditimbulkan akibat dari adanya suatu perkawinan. Kedua, perkawinan yang hanya dilakukan secara agama dan kepercayaan tetap memiliki akibat hukum yang sah menurut negara, karena menurut Pasal 45 Peraturan Pemerintah Nomor 9 Tahun 1975 tentang Peraturan Pelaksanaan Undang-undang Perkawinan dengan tidak dicatatkannya suatu perkawinan hanya akan berakibat dikenakannya hukuman denda, sehingga tidak membuat perkawinan tersebut dinyatakan tidak sah.

Pengaturan tentang anak sah dan hak waris anak sah dalam hukum Islam dan KHI juga memiliki persamaan dan perbedaan. Persamaannya yaitu anak sah dalam hukum Islam dan KHI sama-sama dilahirkan dari perkawinan yang juga dilakukan dengan sah, selain itu dengan adanya status anak sah maka sama-sama akan menimbulkan hubungan nasab dan hubungan perdata antara orang tua dan anaknya. Perbedaannya yaitu dalam hukum Islam untuk membuktikan sah atau tidaknya seorang anak dari sebuah perkawinan dapat cukup dibuktikan dengan adanya pengakuan dari suaminya dan 
anak tersebut nyata terlahir setelah 6 bulan perkawinan dilangsungkan, sedangkan dalam KHI pembuktiannya harus dengan adanya akta kelahiran atau dapat dimungkinkan juga dengan adanya alat bukti lainnya.

Pengaturan tentang anak luar kawin dan hak waris anak luar kawin baik menurut hukum Islam ataupun KHI yaitu bahwa adanya status anak luar kawin berakibat hukum hilangnya hubungan hukum baik itu hubungan perdata ataupun hubungan nasab antara anak luar kawin dengan ayah dan keluarga ayahnya, sehingga hubungan saling mewaris juga tidak akan timbul.

Pengaturan tentang status anak sah dan hak waris anak sah menurut negara dapat disimpulkan bahwa setiap anak dapat dinyatakan sebagai anak sah apabila perkawinan yang dilakukan oleh orang tuanya tersebut sah menurut agama dan kepercayaannya, sedangkan tentang hak waris anak sah dalam hukum negara masih berdasar pada ketentuan KUH Perdata, yaitu Pasal 852 KUH Perdata.

Pengaturan tentang anak luar kawin dan hak waris anak luar kawin menurut hukum negara yaitu bahwa menurut Undangundang Perkawinan, anak luar kawin hanya mempunyai hubungan perdata dengan ibu dan keluarga ibunya, sehingga untuk hubungan saling mewaris juga hanya dengan ibu dan keluarga ibunya. Berbeda dengan ketentuan dalam KUH Perdata yang menguraikan bahwa hubungan anak luar kawin dengan ibunya dan keluarga ibunya tidak dengan sendirinya ada, tetapi harus dengan dilakukannya pengakuan dari orang tuanya sebelum orang tuanya tersebut melangsungkan perkawinan, yang mana dari pengakuan tersebut timbul hubungan perdata diantaranya juga hubungan saling mewaris antara anak luar kawin yang diakui dengan orang tua yang mengakui. Namun, setelah munculnya Putusan Mahkamah Konstitusi Nomor 46/PUU-VIII/2010, status perdata yang juga melahirkan hubungan saling mewaris antara anak yang dilahirkan di luar perkawinan terhadap ayah biologisnya menjadi terlindungi oleh hukum dengan syarat apabila dapat dibuktikan dengan ilmu pengetahuan dan teknologi dan/ atau alat bukti lain.

Anak yang terlahir akibat dari suatu hubungan antara seorang laki-laki dan perempuan dapat dikategorikan menjadi beberapa macam, yaitu dapat dilihat pada gambar berikut:

Gambar 1. tersebut menerangkan bahwa pada dasarnya menurut aturan yang ada dalam perundang-undangan anak terbagi menjadi anak sah dan tidak sah, tapi secara sosiologis tanpa adanya aturan dalam perundang-undangan baik itu dalam Undangundang Perkawinan, KUH Perdata, ataupun dalam KHI juga muncul istilah anak yang diakibatkan dari dilakukannya perkawinan yang tidak dicatatkan.

Istilah perkawinan siridi Indonesia diartikan secara umum sebagai perkawinan yang dilakukan sesuai dengan rukun dan syarat perkawinan menurut agama, tetapi 


\section{Gambar 1. Pengelompokan Status Anak menurut Hukum di Indonesia}

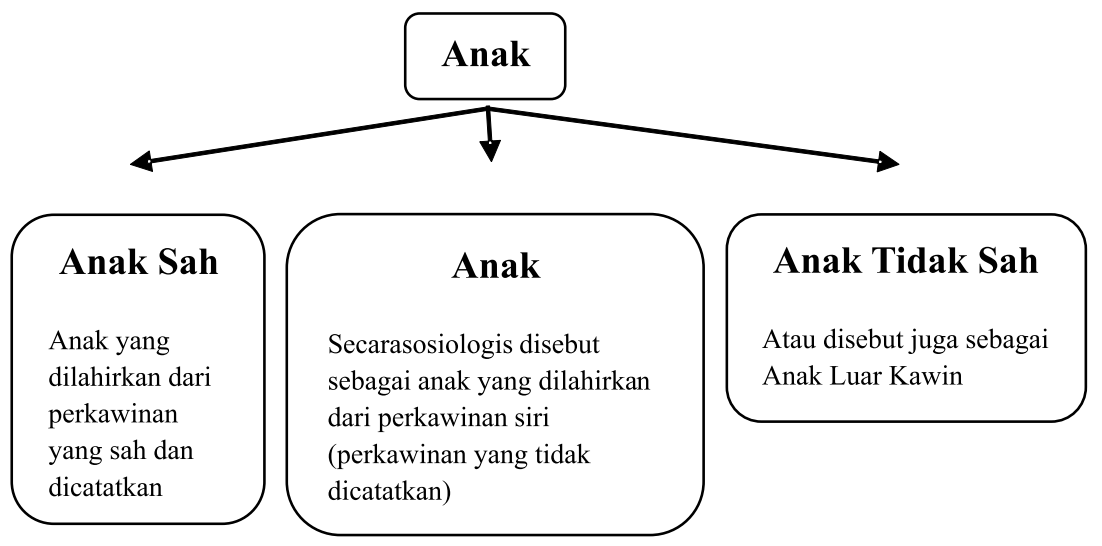

Sumber: bahan hukum sekunder, diolah, 2014

tidak bisa mendapat pengakuan oleh negara karena tidak dilakukannya pencatatan.

Syarat pencatatan dalam suatu perkawinan apabila tidak dilakukan maka di mata hukum akan menimbulkan dampak yang merugikan bagi status anak yang dilahirkan, yaitu anak tersebut hanya mempunyai hubungan perdata dengan ibu dan keluarga ibu, sehingga dalam akta kelahirannyapun statusnya tertulis sebagai anak luar kawin, yang hanya mencantumkan nama ibu yang melahirkannya. Selain itu status tersebut juga mempunyai pengaruh yang sangat mendalam terhadap psikologi anak dan ibunya.

Status hukum yang demikian berakibat hubungan antara ayah dan anak tidak kuat yaitu tidak terwujudnya hubungan perdata dan hubungan nasab antara anak yang dilahirkan dari perkawinan siridengan ayahnya, sehingga dapat dimungkinkan apabila mempunyai itikad yang tidak baik ayahnya dapat menyangkal bahwa anak tersebut adalah anak kandungnya, yang berakibat hilangnya hak anak atas biaya kehidupan dan pendidikan, nafkah dan warisan dari ayahnya tersebut.
Berkaitan status perkawinan siriatau perkawinan siriyang tidak diakui oleh negara, sebenarnya banyak yang berpendapat bahwa hukum negara tetap memberikan ruang bagi penduduk yang beragama Islam atas dilakukannya pencatatan, hal ini dilakukan adalah karena tidak adanya kekuatan legitimasi bagi istri, yaitu dengan cara pengajuan itsbat nikah ke Pengadilan Agama. Mengenai itsbat nikah disebutkan dalam Pasal 7 ayat (2), ayat (3), dan ayat (4) KHI.

Dilihat dari isi Pasal 7 KHI tersebut tidak ada satupun ketentuan yang menyebutkan bahwa kelalaian melakukan pencatatan atas perkawinan yang dilangsungkan dahulu kala, dapat dijadikan sebagai dasar pengajuan itsbat nikah, sehingga rumusan pasal ini masih memerlukan perubahan. Pasal 7 KHI hanya menyebutkan bahwa pengajuan itsbat nikah hanya dapat dilakukan pada perkawinan yang ditujukan untuk penyelesaian perceraian, akta nikah yang hilang, terdapat keraguan tentang sah atau tidaknya dalam memenuhi rukun dan syarat perkawinan, perkawinan tersebut dilangsungkan sebelum berlakunya UndangUndang Perkawinan. 
Melihat dari analisis tersebut ternyata KHI yang awalnya diciptakan untuk mengakui keberlakuan hukum Islam, ternyata masih terdapat rumusan-rumusan yang secara hakiki telah dibenarkan oleh hukum Islam tetapi setelah disesuaikan dengan hukum negara berakibat ketentuan hukum Islam menjadi lemah atau bahkan tidak diakui.

"Menurut Pasal 26 KUH Perdata, Pasal 2 UU Perkawinan Tahun1974, dan Pasal 6 jo.Pasal 15 ayat (3) KHI, terhadap anak sah menurut hukum Islam tetap dihukumi sebagai anak tidak sah karena terlahir akibat dari perkawinan tidak dicatat, maka dengan dasar ini tidak dapat diajukan itsbat nikah karena negara menganggap perkawinan tersebut tidak sah.Oleh karena itu, ketentuan hukum Islam tidak dapat diterapkan dalam peradilan.

Jelas peraturan-peraturan tersebut tidak sesuai dengan syari'at agama Islam karena menyebabkan hilangnya kedudukan anak yang dilahirkan sebagai anak sah menurut hukum Islam selain itu juga menghilangkan hak-hak anak terkait dengan hubungan nasab dan hubungan perdata, sehingga dapat dikatakan bahwa peraturanperaturan tersebut merupakan peraturan yang inkonstitusional karena bertentangan dengan Pasal 1 ayat (3) jo. Pasal 29 ayat (1) dan (2), Pasal 28B, Pasal 28I dan Pasal 28J Undang-undang Dasar Republik Indonesia Tahun 1945."11

Berdasarkan keterangan tersebut dapat disimpulkan bahwa adanya ketentuan pencatatan perkawinan dapat menjadi penghalang untuk diterapkannya hukum Islam, tetapi apabila dipahami secara rasional sebenarnya sebuah perkawinan bagi orang Islam dapat diusahakan oleh pemerintah dengan cara yang lebih manusiawi, yang dapat menjunjung martabat dan hak-hak anak dan istri yang sah menurut hukum perkawinan Islam, yang erat kaitannya dengan tanggung jawab suami.

Terkait dengan adanya pengakuan anak, dalam ajaran agama Islam memang mengenal pengakuan anak, hanya saja pengakuan tersebut ditujukan kepada anak hasil perkawinan yang sah, bukan kepada anak yang terlahir di luar perkawinan sebagaimana ketentuan dalam KUH Perdata, karena dalam Islam telah menetapkan bahwa anak hasil zina hanya mempunyai hubungan hukum dengan ibunya dan keluarga ibunya. Namun, pengakuan tersebut tidak diatur dalam peraturan perundang-undangan negara.

Istilah anak zina didefinisikan sebagai anak yang dilahirkan dari hubungan yang tidak sah, walaupun istilah tersebut telah melekat dalam kehidupan masyarakat, tetapi rumusan pasal dalam KHI tidak menggunakan istilah tersebut untuk dijadikan sebagai istilah yang tercantum dalam pasal-pasalnya. Istilah yang memiliki arti sama dengan 'anak zina' dalam KHI adalah 'anak yang dilahirkan di luar perkawinan'.

"Apabila hukum negara menyebut anak yang lahir dari perkawinan 
sirisebagai anak yang tidak sah, maka otomatis akan berdampak pada tidak adanya hubungan saling mewaris antara anak dengan orang tuanya, padahal dalam hukum Islam mengatur bahwa anak sah yang dilahirkan akibat dari perkawinan yang tidak dicatat tetap dapat diterapkan Hukum Perkawinan Islam dan Hukum Kewarisan Islam terhadap penyelesaian sengketa di luar Pengadilan Agama, sehingga dapat disimpulkan bahwa penerapan Hukum Islam tidak berdasar pada tidak adanya pencatatan suatu perkawinan secara administrasi kenegaraan." 12

Terlihat bahwa hukum Islam yang seharusnya juga dipakai sebagai dasar dibentuknya hukum negara dalam mengatur masyarakat Islam, yang selama ini tertuang dalam bentuk KHI ternyata masih banyak yang belum sesuai dan membutuhkan revisi.

Akibat tidak diakuinya status hukum anak yang dilakhirkan dari perkawinan sirimenurut hukum juga berdampak pada hubungan kewarisan.Pada dasarnya berlakunya hukum kewarisan Islam sangatlah berkaitan dengan kualifikasi seseorang sebagai ahli waris. Pasal 171 huruf c KHI menyebutkan mengenai pengertian ahli waris yaitu orang mempunyai hubungan darah ataupun hubungan semenda dengan pewaris dan ada pada saat pewaris meninggal, selain itu juga harus beragama Islam dan tidak terdapat halangan untuk mewaris.
"Secara umum kualifikasi ahli waris tersebut yaitu orang yang mempunyai hubungan nasab (nasab disini secara haqiqi), yaitu hubungan mushaharah (hubungan karena sebab perkawinan sah), dan hubungan wala' (merdekanya seorang budak)." $" 13$

Namun, pada jaman sekarang yang yang dipakai pedoman adalah hubungan kewarisan yang timbul karena hubungan nasab, tidak ada sebab karena hubungan kewarisan yang ditimbulkan dari hubungan wala', hal ini dikarenakan perbudakan pada jaman sekarang telah dihapuskan karena tidak mangandung nilai kemanusiaan.

Hubungan darah dijadikan sebagai dasar munculnya hubungan perdata, diantaranya termasuk hubungan nasab, hubungan hak dan kewajiban, hubungan kewarisan, hubungan mahram, serta hubungan perwalian. Seorang anak dalam hukum Islam dapat dihubungkan dengan nasab orang tuanya dengan syarat harus memenuhi tiga aspek secara kumulatif, yaitu anak tersebut terlahir dari ikatan perkawinan sah, tidak terlahir dari perbuatan zina, anak berada dalam kandungan ibunya minimal 6 bulan, dimana kehamilan tersebut akibat dari suami istri yang telah melakukan hubungan badan secara nyata.

Berkaitan dengan hak kewarisan seorang anak yang dilahirkan dari perkawinan siriterhadap ayah biologisnya, sampai kapanpun anak tersebut tetap sebagai anak

12 Neng Djubaidah, Op.cit., hlm. 314.

13 Sayyid Sabiq, Fikih Sunnah, Pena Pundi Aksara, Jakarta, 2007, hlm. 484. 
yang memiliki hubungan nasab dengan ayahnya.Oleh karena itu, yang dimaksud hak perdata anak yang dilahirkan dari perkawinan siridalam hubungan kewarisan saat ini adalah status anak yang didapat dari penafsiran Putusan Mahkamah Konstitusi Nomor 46/ PUU-VIII/2010.

Putusan Mahkamah Konstitusi tersebut menguraikan bahwa apabila anak yang terlahir dari perkawinan siri yang dalam hal ini dikatakan sebagai penafsiran dari dengan istilah anak luar kawin, maka anak tersebut dapat membuktikan dengan ilmu pengetahuan bahwa anak tersebut memiliki hubungan darah dengan ayahnya dan apabila terbukti merupakan anak pewaris (anak ayahnya), maka anak tersebut berhak atas bagian waris yang sama dengan ahli waris lainnya. Namun, hasil dari putusan ini masih belum tertuang dalam peraturan pelaksana sehingga masih terdapat kekosongan hukum tentang jaminan hak waris anak yang terlahir dari perkawinan yang tidak dicatatkan.

Apabila dikaji menurut KHI yang dikaitkan dengan hukum Islam dan adanya Undang-Undang Perkawinan, adanya status hukum hak waris anak yang dilahirkan dari perkawinan siriberhubungan dasar terhadap status perkawinan orang tuanya yang tidak sepenuhnya memenuhi persyaratan hukum Islam dan hukum positif negara.

Sahnya perkawinan dalam KHI disebutkan dalam Pasal 4, Pasal 5 dan Pasal 6 KHI. Pasal 4 KHI menguraikan bahwa perkawinan dapat berhukum sah apabila dilakukan sesuai dengan ketentuan dasar agama Islam mengenai perkawinan, yaitu harus memenuhi rukun dan syarat perkawinan, sebagaimana juga tersebut dalam Pasal 2 ayat (1) Undangundang Perkawinan.

Pasal 5 dan Pasal 6 ayat (1) menguraikan bahwa untuk setiap perkawinan diharuskan untuk diikuti dengan pencatatan yang dilakukan oleh dan dengan pengawasan Pegawai Pencatat Nikah, sedangkan Pasal 6 ayat (2) menguraikan bahwa perkawinan yang dilakukan tanpa diikuti dengan pencatatan akan berakibat tidak mempunyai kekuatan hukum. Hal ini dirasa belum sesuai dengan aturan dasar dari sahnya perkawinan menurut ajaran Islam. Padahal apabila dilihat dari Pasal 2 ayat (1) dan (2) Undang-undang Perkawinan jo. Pasal 3 Peraturan Pemerintah Nomor 9 Tahun 1975 tentang Pelaksanaan Undangundang Perkawinan yang bersifat nasional, walaupun menurut pandangan umum pasalpasal tersebut diartikan akan menimbulkan tidak sahnya menurut hukum atau dengan kata lain tidak mempunyai kekuatan hukum, tetapi tidak ada pasal baik dalam Undangundang Perkawinan ataupun Peraturan Pemerintanh Nomor 9 Tahun 1975 tentang Pelaksanaan Undang-undang Perkawinan yang merumuskan bahwa setiap perkawinan yang tidak diikuti dengan pencatatan berakibat tidak mempunyai kekuatan hukum.

Pasal 45 Peraturan Pemerintah Nomor 9 Tahun 1975 tentang Pelaksanaan Undangundang Perkawinan hanya mewajibkan bagi setiap orang yang melanggar Pasal 3 Peraturan 
Pemerintah Nomor 9 Tahun 1975 tentang Pelaksanaan Undang-undang Perkawinan hanya dikenakan denda.

"Teori Kepastian hukum
mengandung dua pengertian yaitu
pertama terwujudnya aturan-aturan
yang dipublikasikan sehingga
masyarakat dapat mengetahui
perbuatan apa saja yang boleh
dan tidak boleh dilakukan, yang
kedua berwujud keamanan hukum
bagi masyarakat dari kesewenang-
wenangan pemerintah."14

Kepastian hukum tidak hanya berwujud pasal-pasal yang terdapat dalam undangundang, melainkan juga dapat terwujud sebagai akibat karena konsistensi dalam putusan hakim yaitu antara putusan hakim yang satu dengan lainnya untuk kasus yang serupa, yang telah diputus sebelumnya.

"Pendapat mengenai kepastian hukum yang dikemukakan oleh Jan M. Otto, yaitu bahwa untuk mewujudkan kepastian hukum diperlukan syarat-syarat yang meliputi:

1. Terdapat aturan hukum dengan rumusan jelas yang dikeluarkan oleh pemerintah, yang mudah didapatkan dan bersifat konsisten;

2. Pemerintah dalam menjalankan tugasnya juga harus taat terhadap aturan-aturan tersebut, hal ini juga berlaku terhadap hakim dalam memutus suatu perkara haruslah bersifat mandiri dan tidak berpihak;

3. Aturan-aturan hukum yang dibuat pada dasarnya direduksi dan disesuaikan terhadap perkembangan masyarakat; dan

4. Suatu putusan hakim secara nyata telah dilaksanakan." 15

Kepastian hukum mengandung arti adanya wujud jaminan terhadap hukum bahwa hukum tersebut telah dilaksanakan sesuai dengan rumusannya.

"Suatu kepastian dapat diperoleh oleh orang berhak dan bahwa suatu putusan hakim secara nyata telah dilaksanakan. Walaupun istilah kepastian hukum memang sangat berkaitan dengan keadilan, tetapi pada dasarnya keduanya berbeda, karena pada hakikatnya istilah keadilan mempunyai sifat subyektif, individualistis, dan tidak menyamaratakan satu sama lain, sedangkan kepastian hukum mempunyai sifat umum, mengikat satu sama lain, serta mempunyai sifat menyamaratakan." 16

Dapat disimpulkan bahwa kepastian hukum dapat dicapai apabila substansi hukumnya sesuai dengan kebutuhan masyarakat. Aturan hukum yang mampu menciptakan kepastian hukum adalah hukum lahir dari dan mencerminkan budaya yang terdapat dalam masyarakat.

14 Peter Mahmud Marzuki, Pengantar Ilmu Hukum, Kencana Pranada Media Group, Jakarta, 2008, hlm. 158.

15 Sidharta, Moralitas Profesi Hukum: Suatu Tawaran Kerangka Berpikir, Refika Aditama, Bandung, 2006, hlm. 85.

16 Sudikno Mertokusumo, Mengenal Hukum suatu Pengantar, Universitas Atma Jaya, Yogjakarta, 2007, hlm. 160. 
Uraian-uraian diatas secara garis besar menyebutkan bahwa kepastian dapat mengandung beberapa arti, yakni adanya kejelasan, tidak menimbulkan multitafsir, tidak menimbulkan kontradiktif, dan dapat dilaksanakan.Kepastian hukum menjadi perangkat hukum suatu negara yang mengandung kejelasan, tidak menimbulkan multitafsir, tidak menimbulkan kontradiktif, dan dapat dilaksanakan, serta dapat menjamin hak dan kewajiban setiap warga negara.

Dapat disimpulkan di satu sisi mungkin ada yang berpendapat bahwa aturan mengenai sahnya perkawinan dalam KHI perlu diperbarui karena belum sesuai dengan syari'at hukum Islam dan Undang-Undang Perkawinan, tetapi pada sisi yang lain seiring perkembangan zaman dan demi kemaslahatan umat Islam perkembangan hukum Islampun dapat berkembang. Setiap pemimpin negara/ khalifah mempunyai hak untuk menetapkan aturan-aturan hukum tertentu yang belum ditetapkan ketentuan dan tata caranya dalam syari'at yang juga wajib ditaati dan diaksanakan oleh masyarakat, sehingga dalam hal ini pemerintah sebagai khalifah mempunyai hak untuk melakukan ijtihad dan menetapkan aturan baru seperti halnya pencatatan perkawinan, dengan demikian pemerintah dapat melindungi setiap peristiwa hukum yang timbul akibat dari adanya perkawinan.

Walaupun seiring perkembangan peradaban pemerintah telah menetapkan peraturan baru tentang pencatatan perkawinan, tetapi apabila pelaksanaan perkawinan tersebut dilakukan dengan tidak dicatatkan akan tetap berdampak terhadap kepastian hukum anak yang dilahirkan dari perkawinan siritersebut karena belum adanya kejelasan aturan dalam KHI, yang berakibat anak tersebut akan dihukumi sebagai anak luar kawin sehingga akan kehilangan hubungan perdata dan hubungan nasab dengan ayah dan keluarga ayahnya, dengan kata lain terhadap anak tersebut juga tidak dapat diberlakukan hukum kewarisan dengan ayah dan keluarga ayahnya.

\section{B. Implikasi Yuridis Status Hukum Hak Waris Anak yang Dilahirkan Hasil dari Perkawinan Siri menurut Kompilasi Hukum Islam}

Hak waris anak yang terlahir dari perkawinan siri tidak diatur secara jelas dalam KHI, hal ini dikarenakan dalam KHI tidak mengenal istilah tersebut, dalam KHI hanya mengenal istilah anak di luar perkawinan. Di mana istilah anak luar kawin menurut pandangan selama ini juga merupakan penafsiran dari istilah anak yang dilahirkan dari perkawinan yang tidak dicatatkan.

Pengertian perkawinan sirimenurut hukum Islam pada jaman dahulu berbeda dengan perkawinan siripada jaman sekarang. Pengertian perkawinan sirisekarang ini di Indonesia, menurut hukum Islam tetap memenuhi rukun dan syarat perkawinan dalam agama Islam hanya saja tidak dicatatkan, sehingga anak yang terlahir dari perkawinan 
siritersebut menurut hukum Islam tetap dihukumi sebagai anak sah.

"Diakui sahnya status seorang anak dari perkawinan siriakan mempunyai akibat dapat diberlakukannya Hukum Perkawinan Islam dan Hukum Kewarisan Islam yang timbul dari adanya hubungan nasab terhadap ayah kandungnya." 17

Berbeda dengan apa yang tercantum dalam KHI, walaupun KHI merupakan perwujudan hukum positif dari hukum Islam, tetapi rumusan pasalnya juga belum seluruhnya sesuai dengan syari'at hukum Islam, hal ini terlihat pada Pasal 6 ayat (2) KHI yang menjelaskan bahwa perkawinan yang dilakukan tanpa disertai dengan adanya pencatatan di bawah pengawasan Pegawai Pencatat Nikah akan berakibat tidak mempunyai kekuatan hukum, sehingga anak yang akan terlahir dari perkawinan yang sebenarnya menurut hukum Islam perkawinan tersebut sah, menjadi ikut menyandang status hukum sebagai anak yang tidak sah yang berakibat terhapusnya hubungan perdata dan hubungan nasab seperti hubungan saling mewaris antara anak tersebut dan ayahnya.

"Padahal dalam syari'at hukum Islam anak yang tidak sah hanya dilahirkan dari hubungan di luar perkawinan yang status hukumnya disamakan dengan anak zina dan anak li'an, sehingga antara anak dan ayahnya dalam hukum Islam mempunyai akibat sebagai berikut: a. tidak menimbulkan hubungan nasab, sehingga ayahnya tidak mempunyai kewajiban untuk memberikan nafkah, tetapi secara biologis anak tersebut tetaplah anaknya.

b. tidak menimbulkan hubungan saling mewaris.

c. ayahnya tidak dapat menjadi wali bagi anak wanita yang dilahirkan di luar nikah." ${ }^{18}$

Tidak adil apabila akibat hukum tersebut juga berlaku terhadap anak yang terlahir dari perkawinan yang tidak dicatatkan, sebagaimana yang tercantum dalam Pasal 6 ayat (2) KHI.

Terkait dengan hukum kewarisan, dengan adanya status perkawinan yang tidak mempunyai kekuatan hukum akan berakibat tidak adanya hubungan saling mewaris antara anak yang dilahirkan dari perkawinan siridengan ayah kandungnya. Apabila dikaji hal ini akan jelas bertentangan dengan adanya teori perlindungan hukum dan teori keadilan.

"TeoriperlindunganhukumSalmond, hukum bertujuan mengintegrasikan dan mengkoordinasikan kepentingan-kepentingan yang terdapat pada masyarakat dalam arti suatu perlindungan terhadap kepentingan tertentu hanya dapat terwujud apabila kepentingan pihak lain dibatasi." 19

Menurut pernyataan tersebut hukum diciptakan dengan menyesuaikan segala

17 M. Nurul Irfan, Nasab dan Status Anak dalam Hukum Islam, Amzah, Jakarta, 2012, hlm. 205.

18 Ibid.

19 Satijipto Raharjo, Ilmu Hukum, Citra Aditya Bakti, Bandung, 2000, hlm. 53. 
kebutuhan yang terdapat dalam perkembangan kehidupan masyarakat, yang direalisasikan dalam bentuk suatu kepentingan, sedangkan kepentingan hukum adalah suatu kepentingan yang mengurusi hak manusia, sehingga dalam hal ini hukum mempunyai kedudukan tertinggi untuk menetapkan kepentingan manusia apa saja yang perlu dilindungi dan tertuang dalam aturan.

Perlindungan hukum diwajibkan berpedoman bahwa perlindungan hukum terwujud karena adanya peraturan-peraturan hukum yang terbentuk dalam kehidupan masyarakat yang pada dasarnya merupakan kesepakatan anggota masyarakat dan antara perseorangan dengan pemerintah yang dianggap dapat mewakili kepentingan masyarakat.

"Perlindungan hukum adalah suatu tindakan memberikan perlindungan terhadap hak asasi manusia yang dirugikan orang lain." ${ }^{20}$

Perlindungan hukum tersebut bertujuan agar setiap manusia dapat menikmati semua hak-hak yang diberikan oleh hukum negara.

"Berlakunya hukum memberikan perlindungan yang bersifat adaptif dan fleksibel, juga prediktif dan antisipatif." 21

Perlindungan hukum diberikan dengan melihat perkembangan kepentingan pada kehidupan masyarakat yang sekarang ataupun yang akan datang.
"Hukum diperlukan untuk setiap manusia yang lemah secara sosial, ekonomi dan politik dalam mendapatkan keadilan sosial." ${ }^{22}$

Pernyataan tersebut menerangkan bahwa perlindungan hukum sangat erat hubungannya dengan terwujudnya keadilan, karena pada hakikatnya setiap diciptakannya aturan hukum bertujuan awal untuk mewujudkan suatu perlindungan hukum dan bertujuan akhir terwujudnya keadilan.

"Bentuk perlindungan hukum kepada masyarakat yang diberikan oleh pemerintah berwujud perlindungan yang bersifat preventif dan represif." ${ }^{23}$

Sifat preventif dalam hal ini memilik tujuan untuk mencegah terjadinya sengketa, dengan wujud adanya kehati-hatian pemerintah dalam tindakan dan mengambil keputusan berdasarkan diskresi, sedangkan sifat represif dalam hal ini memiliki tujuan untuk menyelesaikan terjadinya sengketa, yang terwujud pada proses lembaga peradilan.

Secara leksikal, perlindungan diartikan sebagai tempat berlindung, hal atau perbuatan memperlindungi.Perlindungan diartikan sebagai perbuatan memberi jaminan atau keamanan, ketentraman, kesejahteraan dan kedamaian dari pelindung kepada yang dilindungi atas segala bahaya atau resiko yang mengancamnya.

20 Ibid., hlm. 54.

21 Lili Rasjidi dan I.B Wysa Putra, Hukum sebagai Suatu Sistem, Remaja Rusdakarya, Bandung, 1993, hlm. 118.

22 Sunaryati Hartono, Politik Hukum menuju Satu Sistem Hukum Nasional, Alumni, Bandung, 1991, hlm. 55.

23 Phillipus M. Hadjon, Perlindungan Hukum bagi Rakyat Indonesia, Bina Ilmu, Surabaya, 1987, hlm. 2. 
Keberadaan hukum di Indonesia adalah untuk mengintegrasikan dan mengkoordinasikan kepentingan-kepentingan yang terdapat pada masyarakat.Pengaturan kepentingan tersebut haruslah memiliki keseimbangan antara memberikan kebebasan kepada setiap individu dan melindungi kepentingan masyarakat. Setiap aturan diciptakan oleh hukum akan terwujud apabila setiap subyek hukum diberi hak dan kewajiban.

\section{"Teori keadilan yang dikemukakan oleh John Rawls mengutarakan dan mengangkat teori kontrak sosial ke tingkat abstraksi yang paling tinggi." 24}

Pemikiran tersebut terlihat dari prinsipprinsip keadilan terhadap struktur dasar yang terdapat dalam masyarakat yang merupakan tujuan dari adanya kesepakatan.

Subyek utama dari prinsip keadilan tersebut adalah struktur dasar yang terdapat dalam masyarakat, yang merupakan tatanan institusi-institusi sosial utama yang terwujud dalam satu skema kerjasama.

"Prinsip keadilan yang telah dikemukakan oleh John Rawls, yaitu:

a. Setiap individu mempunyai hak yang sama dengan yang lainnya terhadap sistem kebebasan.

b. Menyeimbangkan kesinambungan sosial dan ekonomi demi terciptanya keuntungan terhadap pihak yang kurang beruntung, serta diletakkan pada jabatan pemerintah yang bersifat terbuka kepada masyarakat berdasarkan kondisi kesetaraan yang adil atas adanya kesempatan." 25

Penjelasan mengenai teori keadilan yang dikemukakan oleh John Rawls di atas memang sangat sulit untuk dipahami, sehingga apabila dijelaskan secara lebih sederhana teori keadilan John Rawls dapat disimpulkan sebagai berikut:

1. Memaksimalkan kemerdekaan.

2. Kesamaan bagi setiap individu, baik kesamaan dalam kehidupan sosial maupun pemanfaatan kekayaan alam.

3. Kesamaan kesempatan terhadap kejujuran, dan penghapusan perlakuan ketidaksamaan berdasarkan kelahiran dan kekayaan.

Teori perlindungan hukum bertujuan untuk menjamin terwujudnya perlindungan setiap hak asasi manusia, agar manusia dapat menikmati semua hak-hak yang diberikan oleh hukum negara. Namun, hal ini belum terwujud dalam status hukum hak waris anak yang dilahirkan dalam perkawinan sirimenurut KHI, yaitu seorang anak yang terlahir dalam keadaan suci tanpa dosa dan juga terlahir dari perkawinan yang menurut syari'at hukum Islam itu sah, tetapi hak-haknya terhadap ayah kandungnya dihapuskan hukum negara.

Teori keadilan pada dasarnya bertujuan untuk mewujudkan terjaminnya kesamaan hak

24 John Rawls, Teori Keadilan (terjemahan A Thery of Justice), Pustaka Pelajar, Yogjakarta, 2006, hlm. 12.

25 Karen Lebacqz, Teori-teori Keadilan (terjemahan six teories of justice), Nusa Media, Bandung, 1986, hlm. 51. 
antar individu sesuai dengan kedudukannya. Hal ini juga belum terwujud dalam status hukum hak waris anak yang dilahirkan dalam perkawinan sirimenurut KHI, apalagi apabila dibandingkan dengan anak angkat yang menurut Pasal 209 ayat (2) KHI, yang menguraikan bahwa anak angkat masih diberi hak atas harta orang tua angkatnya melalui wasiat ataupun wasiat wajibah, jelas di sini belum terlihat terwujudnya keadilan, karena anak angkat yang sebenarnya sama sekali tidak mempunyai hubungan biologis terhadap orang tua angkatnya mempunyai hak atas harta orang tuanya tersebut, berbeda dengan anak yang lahir dari perkawinan siriyang jelas berstatus sebagai anak sah menurut hukum Islam tetapi rumusan KHI menjadikan status hak warisnya terhapuskan, dan kalaupun bisa anak tersebut dapat memperoleh harta ayahnya dari jalan wasiat ataupun wasiat wajibah dipersamakan dengan anak angkat.

Terhadap implikasi yuridis status hukum hak waris anak yang terlahir dari perkawinan siriyang hanya dapat ditafsirkan dari Pasal 6 ayat (2) KHI yang menjadikan anak tersebut dihukumi sebagai anak luar kawin yang hanya mempunyai hubungan saling mewaris dengan ibu dan keluarga ibunya, dan tidak dengan ayah dan keluarga ayahnya yang jelas belum sesuai dengan syari'at hukum Islam, sehingga dapat disimpulkan bahwa rumusan pasal dalam KHI masih perlu diperbaiki terkait dengan sahnya perkawinan serta belum adanya pasal perkawinan siridan status anak yang terlahir dari perkawinan siritersebut, karena dirasa masih belum dapat mewujudkan asas perlindungan hukum dan asas keadilan terhadap masyarakat Islam.

\section{Simpulan}

Makna yuridis status hukum hak waris anak yang terlahir dari perkawinan sirimenurut KHI dapat dikaji berdasar pasal 2 Undang-undang Perkawinan jo. Pasal 3 dan Pasal 45 Peraturan Pemerintah Nomor 9 Tahun 1975 jo. Pasal 6 KHI, bahwa aturan mengenai sahnya perkawinan dalam KHI yang telah disesuaikan dengan perkembangan jaman dan tidak melanggar hukum dasar dari syari'at hukum Islam dan Undang-undang Perkawinan, yaitu mengenai perkawinan siri akan berakibat tidak mempunyai kekuatan hukum, tetapi dilain pihak untuk status hukum anak yang terlahir dari perkawinan siri KHI belum mengatur secara jelas, sehingga anak yang terlahir tersebut dihukumi sebagai anak luar kawin yang akan berdampak terhadap kepastian hukum anak yang dilahirkan dari perkawinan, karena anak tersebut akan kehilangan hubungan perdata dan hubungan nasab dengan ayah dan keluarga ayahnya, sehingga secara otomatis juga akan berakibat hilangnya hubungan saling mewaris dengan ayah dan keluarga ayahnya.

Implikasi yuridis status hukum hak waris anak yang terlahir dari perkawinan siri dapat ditafsirkan dari Pasal 6 ayat (2) KHI yang menjadikan anak tersebut dihukumi sebagai anak luar kawin, yaitu hanya mempunyai hubungan saling mewaris dengan ibu dan 
keluarga ibunya dan tidak dengan ayah dan keluarga ayahnya, sehingga belum terlihat adanya wujud asas perlindungan hukum dan asas keadilan terhadap terhadap anak tersebut.

\section{DAFTAR PUSTAKA}

\section{Buku}

Abdulkadir Muhammad, 2004, Hukum dan

Penelitian Hukum, Citra Aditya Bakti, Bandung.

D. Y. Witanto, 2012, Hukum Keluarga Hak dan Kedudukan Anak Luar Kawin (Pasca Keluarnya Putusan MK tentang Uji Materiil UU Perkawinan),

Prestasi Pustakarya, Jakarta.

H. Hilman Hadikusuma, 2003, Hukum Waris

Adat, Citra Aditya Bakti, Bandung.

John Rawls, 2006, Teori Keadilan

(Terjemahan A Thery of Justice),

Pustaka Pelajar, Yogjakarta.

Kasuwi Saiban, 2007, Hukum Waris Islam,

Universitas Negeri Malang (UM

PRESS), Malang.

Karen Lebacqz, 1986, Teori-teori Keadilan

(terjemahan six teories of justice),

Nusa Media, Bandung.

Lili Rasjidi dan I. B Wysa Putra, 1993,

Hukum sebagai Suatu Sistem, Remaja Rusdakarya, Bandung.

M. Nurul Irfan, 2012, Nasab dan Status

Anak dalam Hukum Islam, Amzah, Jakarta.

Neng Djubaidah, 2010, Pencatatan Perkawinan dan Perkawinan Tidak Dicatat menurut Hukum Tertulis di
Indonesia dan Hukum Islam, Sinar Grafika, Jakarta.

Peter Mahmud Marzuki, 2008, Pengantar Ilmu Hukum, Kencana Pranada Media Group, Jakarta.

Phillipus M. Hadjon, 1987, Perlindungan Hukum bagi Rakyat Indonesia, Bina Ilmu, Surabaya.

Satijipto Raharjo, 2000, Ilmu Hukum, Citra Aditya Bakti, Bandung.

Sayyid Sabiq, 2007, Fikih Sunnah, Pena Pundi Aksara, Jakarta.

Shedharyo Soimin, 2004, Hukum Orang dan Keluarga, Sinar Grafika, Jakarta.

Sidharta, 2006, Moralitas Profesi Hukum: suatu Tawaran Kerangka Berpikir, Refika Aditama, Bandung.

Soerjono Soekanto dan Sri Mahmudji, 2003,

Penelitian Hukum Normatif suatu Tinjauan Singkat, RajaGrafindo Persada, Jakarta.

Sudikno Mertokusumo, 2007, Mengenal Hukum suatu Pengantar, Universitas Atma Jaya, Yogjakarta.

Sunaryati Hartono, 1991, Politik Hukum

Menuju Satu Sistem Hukum

Nasional, Alumni, Bandung.

Wirjono Prodjodikoro, 1983, Hukum

Warisan di Indonesia, Sumur Bandung, Bandung. 
Peraturan Perundangan-undangan

Undang-Undang Dasar Negara Republik Indonesia Tahun 1945.

Kitab Undang-undang Hukum Perdata.

Undang-undang Republik Indonesia Nomor 1 Tahun 1974 tentang Perkawinan, LN No. 1 Tahun 1974, TLN. No. 3019.

Peraturan Pemerintah Nomor 9 Tahun 1975 tentang Pelaksanaan Undang-undang Republik Indonesia Nomor 1 Tahun 1974 tentang Perkawinan.

Kompilasi Hukum Islam.

Putusan Mahkamah Konstitusi Nomor 46/ PUU-VIII/2010 tentang Judicial Review Terhadap Pasal 2 Ayat (2) dan Pasal 43 Ayat (1) Undangundang Perkawinan. 